\title{
Article \\ Effects of Water-to-Cement Ratios on the Properties of Magnesium Potassium Phosphate Cement Prepared with Lithium-Extracted Magnesium Residue
}

\author{
Weixin Zheng ${ }^{1,2,3}$, Jinmei Dong ${ }^{1,2,3, *}$, Jing Wen ${ }^{1,2,3}$, Chenggong Chang ${ }^{1,2,3}$ and Xueying Xiao ${ }^{1,2,3, *}$ \\ 1 Key Laboratory of Comprehensive and Highly Efficient Utilization of Salt Lake Resources, \\ Qinghai Institute of Salt Lakes, Chinese Academy of Sciences, Xining 810008, China; \\ zhengweixin@isl.ac.cn (W.Z.); wj580420@isl.ac.cn (J.W.); ccg168@isl.ac.cn (C.C.) \\ 2 Qinghai Provincial Key Laboratory of Resources and Chemistry of Salt Lake, Xining 810008, China \\ 3 CAS Engineering Laboratory for Green Applications of Salt Lakes and Salt Deposits, Xining 810008, China \\ * Correspondence: dongda839@isl.ac.cn (J.D.); xiaoxy@isl.ac.cn (X.X.)
}

check for updates

Citation: Zheng, W.; Dong, J.; Wen, J.; Chang, C.; Xiao, X. Effects of Water-to-Cement Ratios on the Properties of Magnesium Potassium Phosphate Cement Prepared with Lithium-Extracted Magnesium Residue. Appl. Sci. 2021, 11, 4193. https://doi.org/10.3390/app11094193

Academic Editor: Nocun-Wczelik Wieslawa

Received: 30 March 2021

Accepted: 27 April 2021

Published: 5 May 2021

Publisher's Note: MDPI stays neutral with regard to jurisdictional claims in published maps and institutional affiliations.

Copyright: (c) 2021 by the authors. Licensee MDPI, Basel, Switzerland. This article is an open access article distributed under the terms and conditions of the Creative Commons Attribution (CC BY) license (https:/ / creativecommons.org/licenses/by/ $4.0 /)$.

\begin{abstract}
Salt lake magnesium phosphate cement (SLMKPC) was prepared by mixing potassium dihydrogen phosphate $\left(\mathrm{KH}_{2} \mathrm{PO}_{4}\right)$ with lithium-extracted magnesium residue (MR). The hydrationhardening process and the variation in the phase composition and microstructure of hydration products with the change of the water-cement-ratio $(\mathrm{W} / \mathrm{C})$ were studied by measuring the setting time, hydration exothermic temperature, and compressive strength of the hardened slurry. It was found that $\mathrm{W} / \mathrm{C}$ ratios had significant effects on the setting time, hydration exothermal temperature curve, and compressive strength of SLMKPC. With the increase of W/C, the setting time was prolonged significantly. The exothermic hydration peak temperature first increased and then decreased, and the number of exothermic peaks gradually changed from one to two. The optimal compressive strength was obtained when $\mathrm{W} / \mathrm{C}=0.2-0.3$. Hydration products changed significantly with the increase of $\mathrm{W} / \mathrm{C}$, the $\mathrm{MgKPO}_{4} \cdot 6 \mathrm{H}_{2} \mathrm{O}(\mathrm{MKP})$ in the matrix was more stable when $\mathrm{W} / \mathrm{C}=0.2$ and 0.3 than when $\mathrm{W} / \mathrm{C}=0.25,0.35$, and 0.4 . When $\mathrm{W} / \mathrm{C}=0.3$, SLMKPC had a compact structure with a certain operating space and better mechanical properties.
\end{abstract}

Keywords: magnesium residue; magnesium potassium phosphate cement; water-to-cement ratio; preparation; property

\section{Introduction}

Lithium, as an energy material, plays an important role in mitigation problems caused by fossil fuels. The application of lithium-ion batteries in electric vehicles can reduce environmental pollution caused by traditional vehicles [1,2]. Lithium is abundantly found in salt lake brine [3]. Lithium is mainly extracted from salt lake brine by chemical precipitation for industrial applications [4,5]. In order to remove high $\mathrm{Mg}^{2+}$ concentration, hydroxide or carbonate are generally added, producing a large amount of magnesium residue (MR) [6]. The accumulation of MR in lithium production areas affects the development environment of lithium resources and also causes a serious waste of magnesium resources. It is of great significance to use MR as a raw material to develop other materials and promote the effective utilization of by-products produced by lithium extraction.

It is generally found that MR contains a large amount of magnesium hydrate $\left(\mathrm{Mg}(\mathrm{OH})_{2}\right)$ and magnesium oxide $(\mathrm{MgO})$. These magnesium-containing compounds are favourable raw materials for the synthesis of magnesium phosphate cement (MKPC). MKPC is a chemically bonded ceramic with early strength and fast hardness. MKPC is obtained by the reaction between $\mathrm{MgO}$ and potassium dihydrogen phosphate $\left(\mathrm{KH}_{2} \mathrm{PO}_{4}\right)$ in an aqueous solution [7]. 
Similar to periclase MgO-based binding materials, MKPC is capable of yielding quick hardness and early strength [8-10]; thus, it is extensively used in rapid repairing and biological bone repairing applications, structural coatings, porous ceramics, and waste curing [11-13]. MgO used in MKPC is dead-burned magnesia produced from magnesite ore calcined at $1500-1700{ }^{\circ} \mathrm{C}$ [14]. The demand for high-quality magnesite has increased greatly in recent years [15], and the production of dead-burned magnesia requires higher energy. The high cost of dead-burned $\mathrm{MgO}$ and the shortage of raw ore make MKPC more expensive and limit its practical applications [16].

Moreover, boric acid, alkali, and alkaline earth metal plasma are generally found in salt lake brine [17]; however, it is difficult to completely extract boron [18]. Boric acid $\left(\mathrm{H}_{3} \mathrm{BO}_{3}\right)$ or borax $\left(\mathrm{Na}_{2} \mathrm{~B}_{4} \mathrm{O}_{7} \cdot 10 \mathrm{H}_{2} \mathrm{O}\right)[19,20]$ can significantly regulate acid-base reactions to improve the strength or workability of an MKPC system [21]; therefore, boric acid or borax are used as reaction retarders for MKPC [22].

When MR is used as a magnesium oxide raw material of MKPC, no additional retarder is required, and the retarded time can be regulated by changing the calcination temperature of MR [23-25]. The preparation of MKPC using MR as a raw material consumes a large amount of salt lake by-products to alleviate environmental pollution and reduce the product cost and also makes full use of the characteristics of boron-rich by-products.

Numerous studies have been performed to explore the effects of water-to-cement ratios (W/C) [26,27], magnesia-to-phosphate ratios (Mg/P) [9,28,29], retarders and additives on the properties [21,30-33], and thermal Stability [34,35] of MKPC. It is generally noticed that $\mathrm{W} / \mathrm{C}$ has important effects on the mechanical properties, hydration products, and workability of MKPC [36,37]. The MgO raw material used in these studies was usually commercially available $\mathrm{MgO}$, which has higher purity and stability, and relatively higher price. Tan Y S and Chen W H et al. [23-25] reported that salt lake Magnesium Phosphate Cement (SLMKPC) was prepared by MR and good mechanical properties were obtained. The above studies indicate that it was feasible to use MR instead of Normal MgO for the formation of MKPC materials and the utilization of raw materials. Meanwhile, the economic cost of materials will be greatly reduced due to the reuse of waste resources. Moreover, the $\mathrm{MgO} / \mathrm{KH}_{2} \mathrm{PO}_{4}$ mass ratio also has a significant influence on the hydration heat curve, compressive strength, and porosity of SLMKPC. However, the effects of W/C on the properties of SLMKPC are still not clear.

Therefore, in the present work, the influences of $\mathrm{W} / \mathrm{C}$ ratios on the condensation time, hydration exothermal temperature, and strength performance of SLMKPC were discussed. $X$-ray diffraction (XRD) and scanning electron microscopy (SEM) were used to analyze the microstructures of hydration products and SLMKPC.

\section{Materials and Experimental Procedure}

\subsection{Raw Materials}

Potassium dihydrogen phosphate $\left(\mathrm{KH}_{2} \mathrm{PO}_{4} ; \geq 99 \%\right)$ was purchased from Sinopharm Chemical Reagents Co Ltd. Distilled water was used as a curing liquid and prepared in the laboratory. Magnesium slag with a milky white appearance was obtained as a waste residue after lithium extraction. The magnesium slag was analyzed by chemical titration and $X R D$, and the main chemical components of $\mathrm{MR}$ were $\mathrm{Mg}^{2+}$ and $\mathrm{B}_{2} \mathrm{O}_{3}$ (Table 1). XRD results (Figure 1) revealed that $\mathrm{Mg}^{2+}$ in $\mathrm{MR}$ was a mixture of $\mathrm{MgO}$ and $\mathrm{Mg}(\mathrm{OH})_{2}$. The quantitative analysis in Topas 4.2 software revealed that MR was chemically composed of $\mathrm{Mg}(\mathrm{OH})_{2}(53 \%), \mathrm{MgO}(21 \%), \mathrm{Mg}_{3} \mathrm{~B}_{2} \mathrm{O}_{6}(23 \%), \mathrm{CaCO}_{3}(2 \%)$, and $\mathrm{NaCl}(1 \%)$. A high $\mathrm{MgO}$ is beneficial for the mechanical properties and economy of magnesium-based materials [38]. Therefore, it was necessary to conduct heat treatments on MR to completely convert $\mathrm{Mg}(\mathrm{OH})_{2}$ into $\mathrm{MgO}$. 
Table 1. Chemical composition of the magnesium residue.

\begin{tabular}{lcccccccccccc}
\hline Component & $\mathbf{M g}^{2+}$ & $\mathrm{Ca}^{2+}$ & $\mathbf{B}_{2} \mathbf{O}_{3}$ & $\mathbf{S i O}_{2}$ & $\mathbf{A l}^{3+}$ & $\mathbf{F e}^{2+}$ & $\mathbf{K}^{+}$ & $\mathbf{L i}^{+}$ & $\mathbf{N a}^{+}$ & $\mathbf{C l}^{-}$ & $\mathbf{S O}_{4}{ }^{2-}$ & $\begin{array}{c}\mathbf{L o s s}_{\text {on }} \\
\text { Ignition }\end{array}$ \\
\hline Content (\%) & 39.55 & 0.58 & 4.22 & 0.029 & 0.022 & 0.21 & 0.044 & 0.019 & 0.12 & 0.88 & 0.32 & 25.68 \\
\hline
\end{tabular}

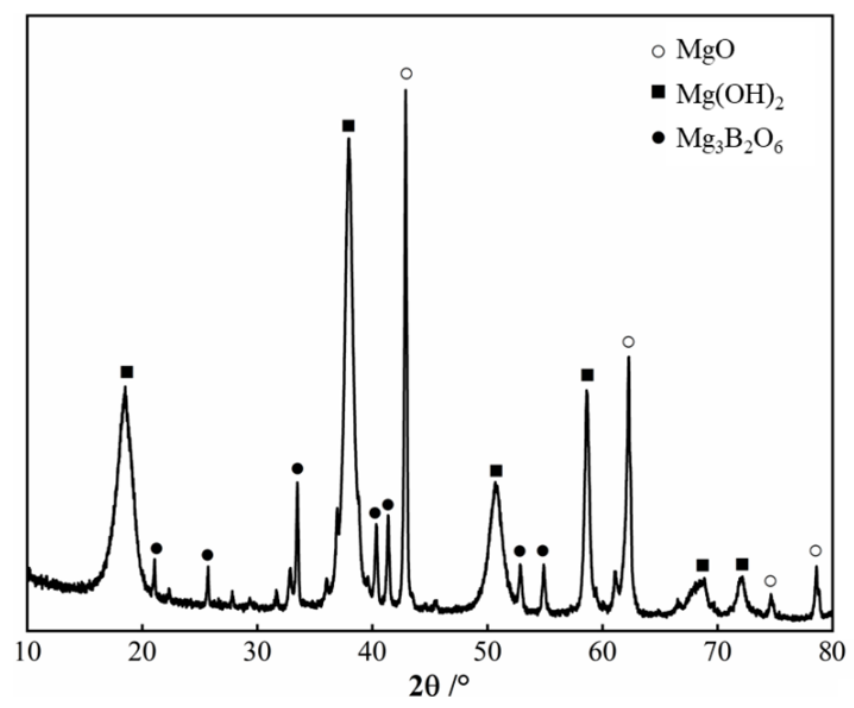

Figure 1. XRD spectrum of MR.

\subsection{Raw Material Handling}

Calcined magnesium residue (CMR) with different $\mathrm{MgO}$ contents was obtained after calcining $\mathrm{MR}$ at different temperatures situation, and $\mathrm{MgO}$ in $\mathrm{CMR}$ had different active $\mathrm{MgO}$ contents $\left(\mathrm{MgO}_{\mathrm{a}}\right)$ at different calcination temperatures. It is observable from Figure 2 that when the calcination temperature increased from $400{ }^{\circ} \mathrm{C}$ to $1200{ }^{\circ} \mathrm{C}$, the activity of $\mathrm{CMR}$ first increased and then decreased and the peak temperature of $\mathrm{MgO}_{\mathrm{a}}$ reached $700{ }^{\circ} \mathrm{C}$. For MPC materials, the activity of magnesium oxide is proportional to the reaction rate, and a fast reaction rate is not effective for sample forming and preparation [39,40]; therefore, it was necessary to find an appropriate temperature condition to maximize the physical properties of SLMKPC.

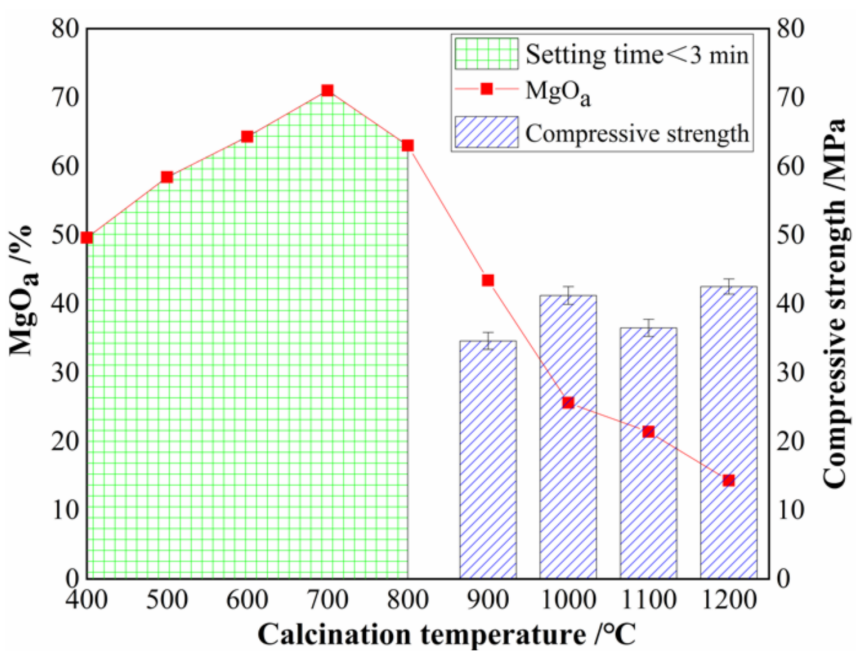

Figure 2. $\mathrm{MgO}_{\mathrm{a}}$ content and compressive strength (curing time = 1 day) changing curve with calcination temperature. 
It is also noticeable from Figure 2 that when the calcination temperature was less than $800^{\circ} \mathrm{C}$, the setting time was less than $3 \mathrm{~min}$ and molded SLMKPC was not obtained when the reaction speed was too fast. However, when the calcination temperature was greater than $900{ }^{\circ} \mathrm{C}$, high-strength SLMKPC was obtained. SLMKPC samples prepared by CMR at the calcination temperatures of $1000{ }^{\circ} \mathrm{C}$ and $1200{ }^{\circ} \mathrm{C}$ had the best mechanical properties (Figure 2). In previous studies [23-25], it was found that MKPC produced by calcined $\mathrm{B}-\mathrm{MgO}\left(100{ }^{\circ} \mathrm{C}\right)$ had good mechanical properties and a long setting time.

According to the above analysis, MR was calcined in advance in this experiment. MR was calcined in a box resistance furnace at $1000{ }^{\circ} \mathrm{C}$ for $1 \mathrm{~h}$ to obtain CMR. After natural cooling, the CMR was crushed to $10 \mathrm{~mm}$ particles, ground in a fast grinding mill for $1.5 \mathrm{~min}$, and then passed through a 120-mesh sieve. The specific surface area and the average particle size were $30.118 \mathrm{~m}^{2} / \mathrm{g}$ and $10.527 \mu \mathrm{m}$, respectively.

\subsection{Mixing Process}

In order to prepare SLMKPC samples, $\mathrm{KH}_{2} \mathrm{PO}_{4}$ was first dried for $180 \mathrm{~min}$ in a vacuum oven at $60{ }^{\circ} \mathrm{C}$, then mixed with $\mathrm{CMR}$, and stirred evenly. The mass ratio of $\mathrm{CMR}$ to $\mathrm{KH}_{2} \mathrm{PO}_{4}$ was 1.5:1, which is typical for MKPC pastes and mortars [25,26]. The mixed powder was then ground in a ball mill for $40 \mathrm{~min}$ and passed through a 200-mesh sieve. Distilled water was mixed with the resultant particles to obtain an SLMKPC slurry.

The slurry was cast in a $20 \mathrm{~mm} \times 20 \mathrm{~mm} \times 20 \mathrm{~mm}$ mold. The specimens were cured at room temperature for 30-60 min, then removed from the mold, and cured in an environment of $20 \pm 3{ }^{\circ} \mathrm{C}$ and $50 \%$ relative humidity. The micro-morphology and mechanical performance of the samples obtained after $60 \mathrm{~min}, 180 \mathrm{~min}, 1 \mathrm{~d}$ (day), $3 \mathrm{~d}, 7 \mathrm{~d}$, $28 \mathrm{~d}, 60 \mathrm{~d}$, and $90 \mathrm{~d}$ of curing were determined.

\subsection{Test Methods}

The setting time of the SLMKPC slurry was determined by a Vicat needle according to the ASTM standard C191 [16]. As SLMKPC could set very fast and its initial setting time was close to the final one; only the final setting time was measured. The hydration exothermic characteristics of the SLMKPC slurry were measured by an automatic temperature recorder. At an ambient temperature of $22 \pm 2{ }^{\circ} \mathrm{C}, 30 \mathrm{~g}$ of SLMKPC dry powder was mixed evenly for standby applications. A certain amount of distilled water was taken according to the $\mathrm{W} / \mathrm{C}$, and its minimum temperature was measured. After $1 \mathrm{~min}$, distilled water was poured into the dry powder, mixed, and stirred evenly, and put into an insulated container. The mechanical performance of SLMKPC was investigated on a universal testing machine (CMT6104; loading speed $=1 \pm 0.5 \mathrm{~mm} / \mathrm{min}$ ).

When SLMKPC reached the critical test period, six parallel samples were tested and the average value was taken as the final compressive strength. The mineralogical compositions of the SLMKPC samples were measured by X-ray (XRD, X'pert Pro PANalytical X'PROPert, Almelo, The Netherlands). XRD spectra were fitted by Bruker AXS (2006) TOPAS 4.2 software (Bruker Company, Billerica, MA, USA), and the quantitative analysis of each phase was carried out by the Rietveld method [41]. SEM (JSM-5610LV, JEOL, Tokyo, Japan) was performed on dried gilded specimens [42].

\section{Results}

\subsection{Effect of W/C Ratios on the Setting Time of SLMKPC Slurry}

Figure 3 presents the relationship between the setting time and W/C ratios of SLMKPC. It is noticeable that $\mathrm{W} / \mathrm{C}$ ratios had a great influence on setting time. With the increase of $\mathrm{W} / \mathrm{C}$, the setting time of SLMKPC was prolonged. When $\mathrm{W} / \mathrm{C}$ was less than 0.3 , the setting time increased greatly. When $W / C=0.25$, the setting time increased by $31 \%$ as compared to that with $\mathrm{W} / \mathrm{C}=0.2$. When $\mathrm{W} / \mathrm{C}=0.3$, the setting time was $24 \%$ higher than that with $\mathrm{W} / \mathrm{C}=0.25$. However, the increment of setting time became slow after $\mathrm{W} / \mathrm{C}=0.3$, and the setting time increased by $15 \%$ and $8 \%$, respectively, as compared to those with $\mathrm{W} / \mathrm{C}$ between 0.35 and $0.3,0.4$, and 0.35 . 


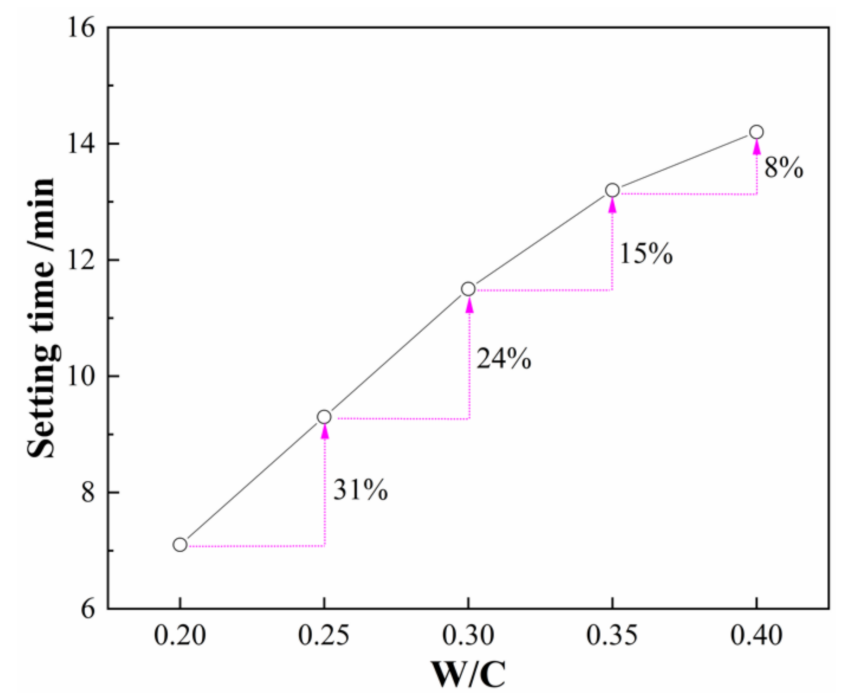

Figure 3. Influence of $\mathrm{W} / \mathrm{C}$ ratios on the setting time of SLMKPC slurry.

The SLMKPC slurry reacted violently with a relatively fast reaction rate when $\mathrm{W} / \mathrm{C}$ was less than 0.35 . When $\mathrm{W} / \mathrm{C}<0.3$, the setting time was below $10 \mathrm{~min}$, whereas when $\mathrm{W} / \mathrm{C}=0.3$, the setting time was above $10 \mathrm{~min}$. Therefore, a high $\mathrm{W} / \mathrm{C}$ ratio was helpful to prolong the hydration reaction time of the SLMKPC slurry, and $\mathrm{W} / \mathrm{C}=0.3$ was the optimal value for the SLMKPC slurry setting time.

\subsection{Effects of W/C Ratios on the Hydration Temperature Curve of SLMKPC Slurry}

Figure 4 displays the variation trend of the hydration exothermic curve of SLMKPC with W/C in $400 \mathrm{~min}$. The hydration exothermal curve of the SLMKPC slurry had an acceleration period in the beginning, and the hydration heat reached the peak and decreased slowly with the prolonged time. The exothermic peak of hydration manifested different characteristics with the changing $\mathrm{W} / \mathrm{C}$ ratio.

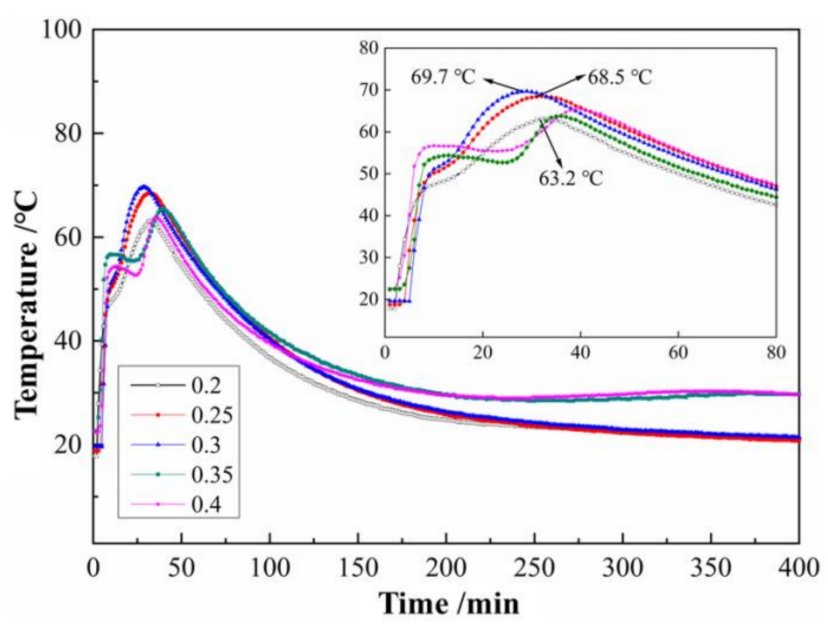

Figure 4. Influence of $\mathrm{W} / \mathrm{C}$ ratios on the hydration heat release characteristics of SLMKPC slurry.

When $\mathrm{W} / \mathrm{C}<0.3$, only one exothermic peak was detected and the maximum exothermic peak temperatures corresponding to $\mathrm{W} / \mathrm{C}=0.2,0.25$, and 0.3 were $63.2^{\circ} \mathrm{C}, 68.5^{\circ} \mathrm{C}$, and $69.7^{\circ} \mathrm{C}$, respectively. It implies that the hydration reaction of SLMKPC became more violent in the $\mathrm{W} / \mathrm{C}$ range of $0.2-0.3$. When $\mathrm{W} / \mathrm{C}=0.2$, the moisture content in the SLMKPC slurry was insufficient to allow all $\mathrm{CMR}$ and $\mathrm{KH}_{2} \mathrm{PO}_{4}$ to react. When the $\mathrm{W} / \mathrm{C}$ ratio increased from 0.2 to $0.3, \mathrm{CMR}$ and $\mathrm{KH}_{2} \mathrm{PO}_{4}$ completely reacted with water, and subsequently, the highest exothermic temperature of hydration was obtained at $\mathrm{W} / \mathrm{C}=0.3$. 
When the $\mathrm{W} / \mathrm{C}$ ratio increased from 0.35 to 0.4 , the number of hydration exothermic peaks changed from one to two, and the maximum temperature of the first exothermic peak was lower than that of the second one. When $\mathrm{W} / \mathrm{C}=0.4$, the exothermic peak temperature of hydration was less than that with $\mathrm{W} / \mathrm{C}=0.35$, indicating that the excessive liquid played a certain blocking effect on the reaction of the slurry and reduced the exothermic reaction temperature.

\subsection{Effects of W/C Ratios on the Compressive Strength of SLMKPC}

Figure 5 expresses the effects of W/C ratios on the compressive strength of SLMKPC. The pre-compressive strength $(\leq 1 \mathrm{~d})$ of SLMKPC decreased with the increase of W/C, whereas the long-term strength $(\geq 3 \mathrm{~d})$ first increased and then decreased with the increase of $\mathrm{W} / \mathrm{C}$. When $\mathrm{W} / \mathrm{C}=0.25$, the compressive strength of SLMKPC after each aging period was high. When $\mathrm{W} / \mathrm{C} \leq 0.25$, the compressive strength of the hardening body was the highest, whereas the compressive strength after $1 \mathrm{~h}$ of aging was $70 \%$ higher than that after $28 \mathrm{~d}$ of aging. The pre-compressive strength of SLMKPC was relatively low when W/C was greater than 0.30 , whereas the long-term strength was significantly high.

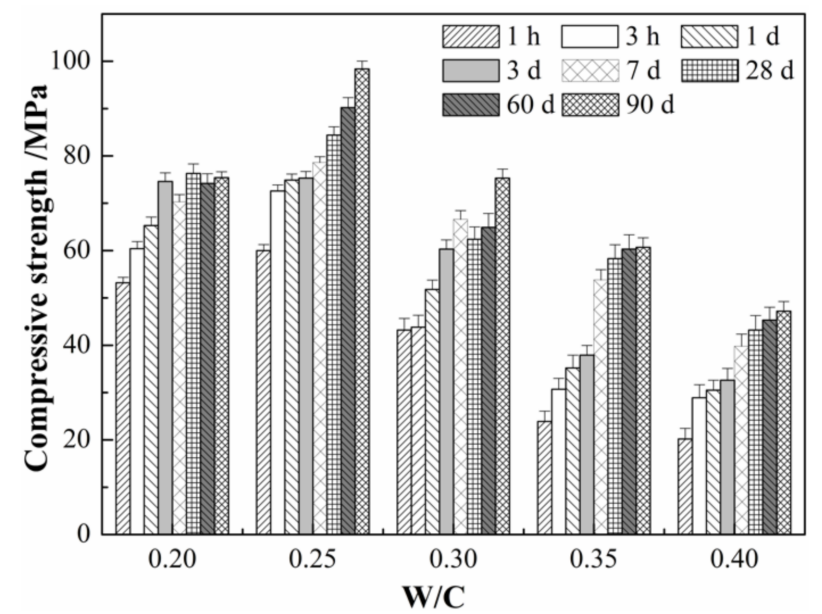

Figure 5. Influence of $\mathrm{W} / \mathrm{C}$ ratios on the compressive strength of SLMKPC sample.

The compressive strength differences of different $\mathrm{W} / \mathrm{C}$ samples after $3 \mathrm{~d}$ and $28 \mathrm{~d}$ of curing were $\Delta_{\mathrm{W} / \mathrm{C}}=0.2=1.7 \mathrm{MPa}, \Delta_{\mathrm{W} / \mathrm{C}}=0.25=3.1 \mathrm{MPa}, \Delta_{\mathrm{W} / \mathrm{C}}=0.3=2.1 \mathrm{MPa}, \Delta_{\mathrm{W} / \mathrm{C}}=0.35=20.4 \mathrm{MPa}$,

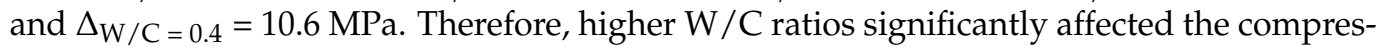
sive strength of SLMKPC. When $W / C=0.35-0.4$, the compressive strength of SLMKPC was noticeably lower than that at $\mathrm{W} / \mathrm{C}=0.2-0.3$.

\subsection{Effecst of W/C Ratios on the Phase Composition of SLMKPC}

Figure $6 \mathrm{a}, \mathrm{b}$ displays the phase compositions of SLMKPC after $3 \mathrm{~d}$ and $28 \mathrm{~d}$ of aging at different $\mathrm{W} / \mathrm{C}$ ratios, respectively. The main hydration products of SLMKPC were MKP, $\mathrm{MgO}$, and $\mathrm{Mg}_{3} \mathrm{~B}_{2} \mathrm{O}_{6}$.

A little variation was detected in the XRD patterns of SLMKPC samples prepared at different $\mathrm{W} / \mathrm{C}$ ratios, indicating that the change of $\mathrm{W} / \mathrm{C}$ had no effect on the phase composition of hydration products. The quantitative analysis of SLMKPC samples with different $\mathrm{W} / \mathrm{C}$ ratios after $3 \mathrm{~d}$ and $28 \mathrm{~d}$ of aging was carried out in Topas 4.2 software (Figure 6c), and a significant difference was noticed in the phase composition of the samples.

The quantity of MKP in the samples with different $\mathrm{W} / \mathrm{C}$ ratios after $3 \mathrm{~d}$ of aging was relatively small and increased to different degrees after $28 \mathrm{~d}$. The growth rate of MKP at $\mathrm{W} / \mathrm{C}=0.35-0.4$ was greater than that at $\mathrm{W} / \mathrm{C}=0.2-0.3$, and it is consistent with the development rule of compressive strength. When $\mathrm{W} / \mathrm{C}=0.2-0.35$, the amount of MKP was relatively high, whereas when $\mathrm{W} / \mathrm{C}=0.35-0.4$, the amount of MKP was relatively 
small. Moreover, the amount of MKP changed with the increase of the W/C ratio and the critical period.
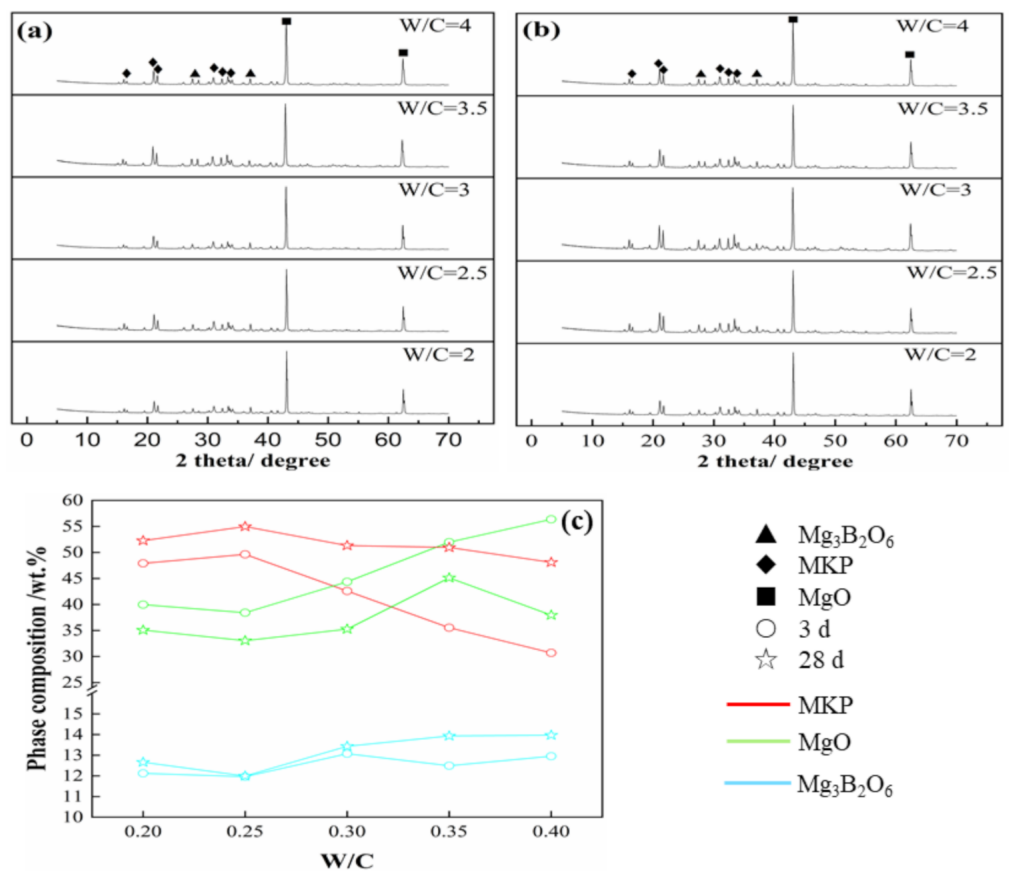

Figure 6. Influence of $\mathrm{W} / \mathrm{C}$ ratios on the phase composition of SLMKPC: (a) After $3 \mathrm{~d}$ of curing, (b) after $28 \mathrm{~d}$ of curing, (c) TOPAS quantitative analysis of the phase compositions of SLMKPC at different $\mathrm{W} / \mathrm{C}$ ratios.

\subsection{Effects of W/C Ratios on the Microstructure of SLMKPC}

Figure 7 exhibits the micro-morphologies of SLMKPC samples with different W/C ratios after $28 \mathrm{~d}$ of curing. When $\mathrm{W} / \mathrm{C}=0.2$, the SLMKPC sample was composed of a large number of rod-like crystals, which were closely spliced together to form a thin and dense sheet structure consisting of a few micro-cracks (Figure 7a). When the $\mathrm{W} / \mathrm{C}$ ratio increased to 0.25 , a large number of columnar hydration products existed in the hardened SLMKPC sample with a high degree of crystallization (Figure $7 \mathrm{~b}$ ). These hydration products were tightly packed with each other, no cracks were detected in the microstructure, and the highest compressive strength was obtained. When $\mathrm{W} / \mathrm{C}=0.3-0.4$, the fracture and crystallization degrees of hydration products were the worst; hence, the overall structure of the sample was loose due to the existence of small cracks and voids (Figure 7c-e). When W/C $=0.35-0.4$, crystals ruptured into granular ones (Figure 7d,e); hence, the compressive strength was low due to the loose crystal structure (Figure 5). 

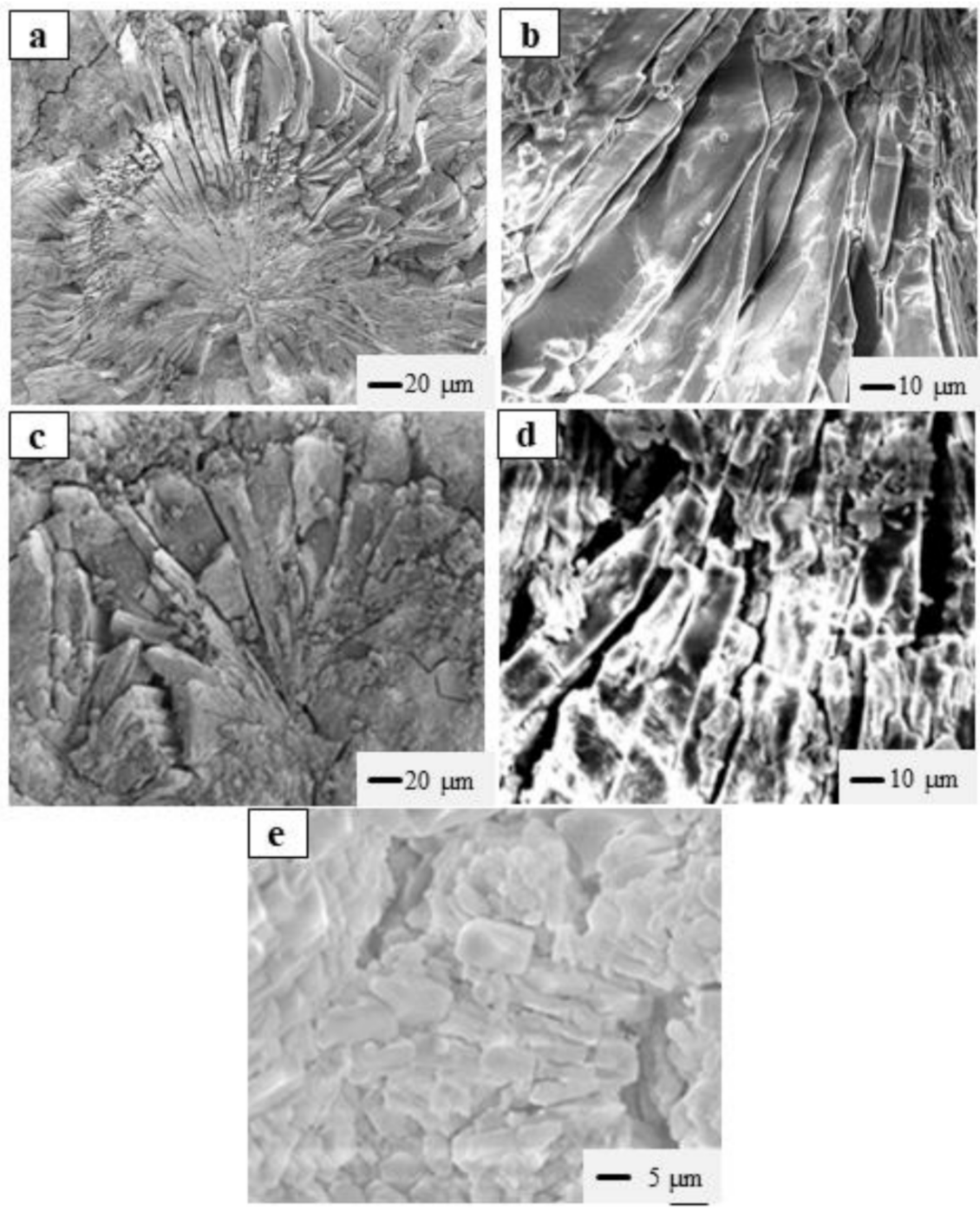

Figure 7. SEM images of SLMKPC samples with different $\mathrm{W} / \mathrm{C}$ ratios after at $28 \mathrm{~d}$ of aging: (a) $\mathrm{W} / \mathrm{C}=0.2,(\mathbf{b}) \mathrm{W} / \mathrm{C}=0.25$, (c) $\mathrm{W} / \mathrm{C}=0.3$, (d) $\mathrm{W} / \mathrm{C}=0.35$, (e) $\mathrm{W} / \mathrm{C}=0.4$.

\section{Discussion}

It is evident from Figure 3 that a large $\mathrm{W} / \mathrm{C}$ ratio resulted in a longer setting time. In addition to a large $\mathrm{W} / \mathrm{C}$ ratio, an optimal $\mathrm{W} / \mathrm{C}$ range enabled SLMKPC to obtain the best mechanical properties with a better operating space. The performance of MKPC was limited by a reasonable $\mathrm{W} / \mathrm{C}$ range.

It is noticeable from Figure 8 a that when W/C $>0.4$, the slurry was very watery. Due to the presence of excess water in the solidification process, the porosity of the final sample was too large (Figure 7e); thus, the SLMKPC sample had a loose structure and low mechanical properties (Figure 5). The SLMKPC slurry was very dry at W/C $<0.2$ (Figure $8 \mathrm{c}$ ) and could not achieve operational capability due to excessive moisture loss. The optimal value $\mathrm{Mg} / \mathrm{P}$ was dependent on the $\mathrm{W} / \mathrm{C}$ ratio [22]. A W/C ratio of greater than 0.2 was sufficient to guarantee a complete reaction of $\mathrm{KH}_{2} \mathrm{PO}_{4}$ [43]. Therefore, the optimal $\mathrm{W} / \mathrm{C}$ range for the best setting performance of SLMKPC was 0.2-0.4.

When $\mathrm{W} / \mathrm{C}$ was between $0.2-0.3$, only one exothermic peak appeared in the initial hydration stage (Figure 4). When $\mathrm{W} / \mathrm{C}=0.2$, the moisture content in the SLMKPC slurry was insufficient to allow all $\mathrm{CMR}$ and $\mathrm{KH}_{2} \mathrm{PO}_{4}$ to react. Due to the residual part of $\mathrm{MgO}$ in the $\mathrm{CMR}$, the hydration heat release rate and total amount were relatively low under the condition of the same raw materials. When the $\mathrm{W} / \mathrm{C}$ ratio increased from 0.2 to $0.3, \mathrm{CMR}$ and $\mathrm{KH}_{2} \mathrm{PO}_{4}$ completely reacted with water and reached a critical point, 
resulting in the highest exothermic hydration temperature. The formation of MKPC was accompanied by a typical heat evolution curve consisting of an endothermic valley and two exothermic peaks [16]. The results show that the purity and stability of the raw material can be guaranteed because the raw material of MKPC is commercial $\mathrm{MgO}$. Therefore, two exothermic peaks can be obtained in the W/C of MKPC at different stages. Two exothermic peaks only appeared when $\mathrm{W} / \mathrm{C}$ was adjusted to a certain proportion in the SLMKPC slurry. When the W/C increased from 0.35 to 0.4 , the number of exothermic peaks in the SLMKPC slurry changed from one to two (Figure 4).

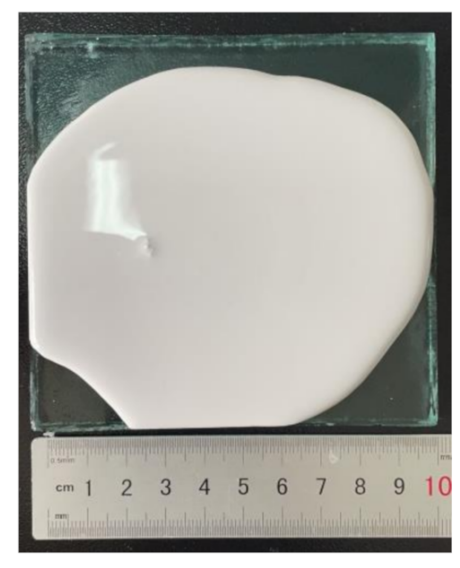

(a) $\mathrm{W} / \mathrm{C}>0.4$

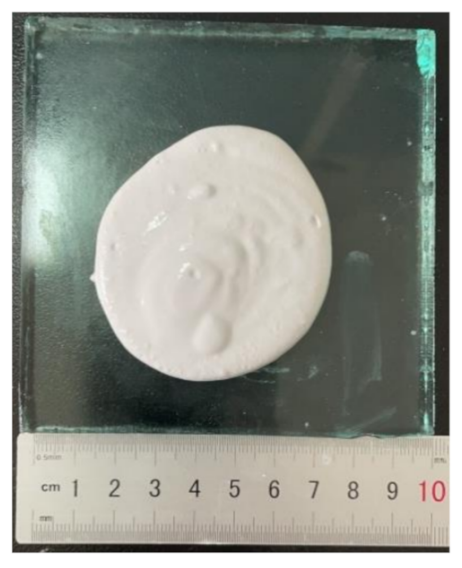

(b) $\mathrm{W} / \mathrm{C}=0.25$

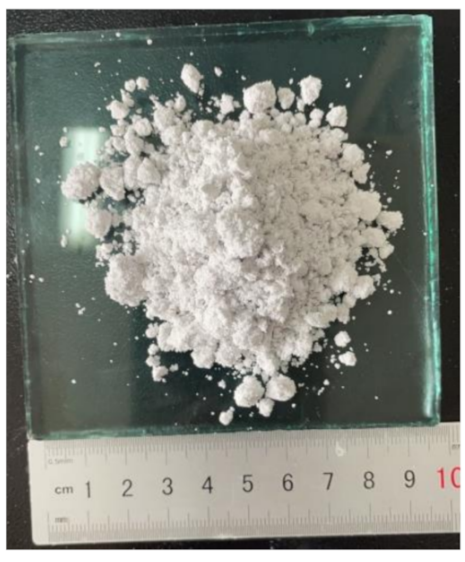

(c) $\mathrm{W} / \mathrm{C}<0.2$

Figure 8. Influence of $\mathrm{W} / \mathrm{C}$ ratios on the setting performance of SLMKPC.

In the SLMKPC system with only one exothermic peak, a large amount of heat concentrated to release, resulting in a partial performance loss in the later period. Moreover, this exothermic peak had no significant effect on the mechanical properties and microstructure of the material. In contrast, the SLMKPC system with two exothermic peaks (W/C $=0.35-0.4$ ) reduced the exothermic temperature and slowed down the rate of hydration (Figure 5); however, a large $\mathrm{W} / \mathrm{C}$ ratio resulted in inferior mechanical properties (Figure 5) and a loose microstructure (Figure 7).

The typical setting time of an MPC system without a retarder is less than $3 \mathrm{~min}$ [16], and it can be extended to above $20 \mathrm{~min}$ after the addition of boric acid, mineral ingredients, and other retarders [44]. However, the setting time of SLMKPC without any retarder could not reach above $20 \mathrm{~min}$ [34]. When $\mathrm{W} / \mathrm{C}>0.3$, the setting time reached above $10 \mathrm{~min}$. Therefore, in order to convert a large quantity of MR feedstock into usable SLMKPC, the setting time corresponding to $\mathrm{W} / \mathrm{C}=0.2-0.3$ should be considered.

According to Equation (1), the amount of $\mathrm{MgO}$ in the system decreased with the increase of the MKP content during the reaction. The quantitative analysis of SLMKPC (Figure 6c) revealed that the quantities of $\mathrm{MgO}$ and MKP in all SLMKPC samples after $3 \mathrm{~d}$ of curing were higher than those after $28 \mathrm{~d}$ of curing, and this phenomenon is different from the MKP generation process. $\mathrm{Mg}_{3} \mathrm{~B}_{2} \mathrm{O}_{6}$ played a regulating role in the absorption and release of $\mathrm{MgO}$ in the system because the boron compound precipitated around $\mathrm{MgO}$ grains in the reaction or formed a magnesium borate complex $[45,46]$. With the prolongation of the critical period, the precipitated magnesium borate complex was decomposed and released a small number of $\mathrm{MgO}$ grains.

Hydration products were the strength of the MKPC system [26-30]. It is noticeable from Figure $6 c$ that although the amount of MKP in SLMKPC after 3 days was smaller than that after 28 days, the difference was not very large; however, the intensity difference was obvious. The compressive strength differences of different $\mathrm{W} / \mathrm{C}$ samples after $3 \mathrm{~d}$ and $28 \mathrm{~d}$ of curing were $\Delta_{\mathrm{W} / \mathrm{C}=0.2}=1.7 \mathrm{MPa}, \Delta_{\mathrm{W} / \mathrm{C}=0.25}=3.1 \mathrm{MPa}, \Delta_{\mathrm{W} / \mathrm{C}=0.3}=2.1 \mathrm{MPa}, \Delta_{\mathrm{W} / \mathrm{C}=0.35}=20.4 \mathrm{MPa}$, and $\Delta_{\mathrm{W} / \mathrm{C}=0.4}=10.6 \mathrm{MPa}\left(\Delta_{\mathrm{W} / \mathrm{C}=0.2}<\Delta_{\mathrm{W} / \mathrm{C}=0.3}<\Delta_{\mathrm{W} / \mathrm{C}=0.25}<\Delta_{\mathrm{W} / \mathrm{C}=0.4}<\Delta_{\mathrm{W} / \mathrm{C}=0.35}\right)$. 
It is clear that the stability of SLMKPC samples with different W/C ratios was different. The SLMKPC system with $\mathrm{W} / \mathrm{C}=0.2$ and 0.3 was more stable than those with $\mathrm{W} / \mathrm{C}=0.25$, 0.35 , and 0.4. When $\mathrm{W} / \mathrm{C}=0.3, \mathrm{SLMKPC}$ had the best mechanical properties (Figure 5) and a compact structure (Figure 7) [47]. Generally, the W/C of MKPC prepared with commercially available $\mathrm{MgO}$ is between $0.2-0.25$, in which MKPC has the highest mechanical properties [46]. The optimal $\mathrm{W} / \mathrm{C}=0.3$ for SLMKPC is slightly higher than when $\mathrm{W} / \mathrm{C}=0.25$, which may be caused by the fact that MR has more impurities and a larger specific surface than commercially available $\mathrm{MgO}$.

\section{Conclusions}

(1) As MR contains a large amount of $\mathrm{Mg}(\mathrm{OH})_{2}$, when the calcination temperature was less than $800^{\circ} \mathrm{C}$, its setting time was less than 3 min; hence, SLMKPC samples could not be obtained at a too fast reaction speed. When the reaction between raw materials occurred at a temperature greater than $900{ }^{\circ} \mathrm{C}$, strong SLMKPC samples were obtained.

(2) $\mathrm{W} / \mathrm{C}$ ratios had strong effects on the condensation time, hydration exothermic temperature, and compressive strength of SLMKPC. The setting time increased from $7 \mathrm{~min}$ to $12 \mathrm{~min}$ with the increase of $\mathrm{W} / \mathrm{C}$ from 0.2 to 0.4 . The exothermic hydration peak temperature first increased and then decreased, and the number of exothermic peaks gradually changed from one to two. The compressive strength of SLMKPC first increased and then decreased with the increase of $\mathrm{W} / \mathrm{C}$, and the optimal compressive strength was obtained when $\mathrm{W} / \mathrm{C}=0.25$.

(3) The SLMKPC system without any retarder had a longer setting time than the MPC system without any retarder. When $W / C>0.2$, the setting time reached more than $7 \mathrm{~min}$. In order to convert a large amount of MR into applicable SLMKPC, the setting time corresponding to $\mathrm{W} / \mathrm{C}=0.2-0.3$ should be considered.

(4) With the increase of W/C, the morphology and structure of hydration products in SLMKPC gradually became loose and the number of cracks simultaneously increased. When $W / C=0.2-0.3$, hydrated products of SLMKPC had a high degree of crystallization and a regular columnar arrangement and the matrix had a dense structure with few microcracks.

(5) $\mathrm{B}^{3+}$ ions played a retarding role in the SLMKPC system. The content of $\mathrm{Mg}_{3} \mathrm{~B}_{2} \mathrm{O}_{6}$ in SLMKPC after $28 \mathrm{~d}$ of curing was higher than that after $3 \mathrm{~d}$. It indicates that $\mathrm{B}^{3+}$ ions involved in the deposition of magnesia grains in SLMKPC were released slowly with the increasing curing time.

(6) The main hydration product of SLMKPC at different ages was MKP. The compressive strength differences of different $\mathrm{W} / \mathrm{C}$ samples after $3 \mathrm{~d}$ and $28 \mathrm{~d}$ of curing were $\Delta_{\mathrm{W} / \mathrm{C}=0.2}=1.7 \mathrm{MPa}, \Delta_{\mathrm{W} / \mathrm{C}=0.25}=3.1 \mathrm{MPa}, \Delta_{\mathrm{W} / \mathrm{C}=0.3}=2.1 \mathrm{MPa}, \Delta_{\mathrm{W} / \mathrm{C}=0.35}=20.4 \mathrm{MPa}$, and $\Delta_{\mathrm{W} / \mathrm{C}=0.4}=10.6 \mathrm{MPa}\left(\Delta_{\mathrm{W} / \mathrm{C}=0.2}<\Delta_{\mathrm{W} / \mathrm{C}=0.3}<\Delta_{\mathrm{W} / \mathrm{C}=0.25}<\Delta_{\mathrm{W} / \mathrm{C}=0.4}<\Delta_{\mathrm{W} / \mathrm{C}=0.35}\right)$. The SLMKPC systems with $\mathrm{W} / \mathrm{C}=0.2$ and 0.3 were more stable than those with $\mathrm{W} / \mathrm{C}=0.25$, 0.35 , and 0.4 . Therefore, MR calcined at $1000{ }^{\circ} \mathrm{C}$ could produce excellent SLMKPC with a compact structure, a certain operating space, and better mechanical properties when $\mathrm{W} / \mathrm{C}=0.3$.

Author Contributions: All authors discussed and agreed upon the idea, and made scientific contributions: writing —original draft preparation, W.Z. and X.X.; experiment designing, J.W.; experiment performing, C.C.; data analysis, W.Z.; writing-review and editing, W.Z. and J.D. All authors have read and agreed to the published version of the manuscript.

Funding: The authors would like to acknowledge the financial support from the Fund of Applied Basic Research Project of Qinghai Province, China (2020-ZJ-746, 2021-ZJ-750); The Major Science and Technology Projects of Xining City, China (2019-Z-08); The Youth Innovation Promotion Association of Chinese Academy of Sciences (2019423) and the High-end Innovative Talents Thousand Talents Plan of Qinghai Province, China.

Institutional Review Board Statement: Not applicable.

Informed Consent Statement: Not applicable. 
Data Availability Statement: No new data were created or analyzed in this study. Data sharing is not applicable to this article.

Conflicts of Interest: The authors declare no conflict of interest.

\section{References}

1. Tadesse, B.; Makuei, F.; Albijanic, B.; Dyer, L. The beneficiation of lithium minerals from hard rock ores: A review. Miner. Eng. 2019, 131, 170-184. [CrossRef]

2. Angermeier, S.; Ketterer, J.; Karcher, C. Liquid-Based Battery Temperature Control of Electric Buses. Energies 2020, 13, 4990. [CrossRef]

3. Sun, Y.; Wang, Q.; Wang, Y.; Yun, R.; Xu, X. Recent advances in magnesium/lithium separation and lithium extraction technologies from salt lake brine. Sep. Purif. Technol. 2021, 256, 117807. [CrossRef]

4. Swain, B. Recovery and recycling of lithium: A review. Sep. Purif. Technol. 2017, 172, 388-403. [CrossRef]

5. $\quad \mathrm{Li}, \mathrm{B} . ; \mathrm{Wu}, \mathrm{J}$.; Lu, J. Life cycle assessment considering water-energy nexus for lithium nanofiltration extraction technique. J. Clean. Prod. 2020, 261, 121152. [CrossRef]

6. Kong, R.; Xue, F.; Wang, J. Research on Mineral Resources and Environment of Salt Lakes in Qinghai Province based on System Dynamics Theory. Resour. Policy 2017, 52, 19-28. [CrossRef]

7. Campos, M.D.; Davy, C.A.; Djelal, N.; Rivenet, M.; Garcia, J. Development of a stoichiometric magnesium potassium phosphate cement (MKPC) for the immobilization of powdered minerals. Cem. Concr. Res. 2021, 142, 106346. [CrossRef]

8. Li, Y.; Shi, T.; Li, Y.; Bai, W.; Lin, H. Damage of magnesium potassium phosphate cement under dry and wet cycles and sulfate attack. Constr. Build. Mater. 2019, 210, 111-117. [CrossRef]

9. Brückner, T.; Meininger, M.; Groll, J.; Kübler, A.C.; Gbureck, U. Magnesium Phosphate Cement as Mineral Bone Adhesive. Materials 2019, 12, 3819. [CrossRef]

10. Zhang, L.; Jiang, Z.; Zhang, W.; Peng, S.; Chen, P. Flexural Properties and Microstructure Mechanisms of Renewable Coir-FiberReinforced Magnesium Phosphate Cement-Based Composite Considering Curing Ages. Polymers 2020, 12, 2556. [CrossRef]

11. Du, Y.; Gao, P.; Yang, J.; Shi, F. Research on the Chloride Ion Penetration Resistance of Magnesium Phosphate Cement (MPC) Material as Coating for Reinforced Concrete Structures. Coatings 2020, 10, 1145. [CrossRef]

12. Huete-Hernandez, S.; Maldonado-Alameda, A.; Giro-Paloma, J.; Chimenos, J.M.; Formosa, J. Fabrication of sustainable magnesium phosphate cement micromortar using design of experiments statistical modelling: Valorization of ceramic-stone-porcelain containing waste as filler. Ceram. Int. 2021, 47, 10905-10917. [CrossRef]

13. Pyo, J.; Um, W.; Heo, J. Magnesium potassium phosphate cements to immobilize radioactive concrete wastes generated by decommissioning of nuclear power plants. Nucl. Eng. Technol. 2021. [CrossRef]

14. Ding, Z.; Dong, B.; Xing, F.; Han, N.; Li, Z. Cementing mechanism of potassium phosphate based magnesium phosphate cement. Ceram. Int. 2012, 38, 6281-6288. [CrossRef]

15. Tang, Y.; Yao, J.; Yin, W.; Kelebek, S. Molecular Dynamics Simulation of Cetyl Phosphate Adsorption in Flotation of Magnesite and Pertinent Chemical Aspects. Minerals 2020, 10, 761. [CrossRef]

16. Qiao, F.; Chau, C.; Li, Z. Setting and compressive strength characteristics of magnesium phosphate cement paste. Adv. Cem. Res. 2009, 21, 175-180. [CrossRef]

17. Shi, D.; Zhang, L.; Peng, X.; Li, L.; Song, F.; Nie, F.; Ji, L.; Zhang, Y. Extraction of lithium from salt lake brine containing boron using multistage centrifuge extractors. Desalination 2018, 441, 44-51. [CrossRef]

18. Zhang, R.; Xie, Y.; Song, J.; Xing, L.; Kong, D.; Li, X.; He, T. Extraction of boron from salt lake brine using 2-ethylhexanol. Hydrometallurgy 2016, 160, 129-136. [CrossRef]

19. Hall, D.A.; Stevens, R.; El-Jazairi, B. The effect of retarders on the microstructure and mechanical properties of magnesiaphosphate cement mortar. Cem. Concr. Res. 2001, 31, 455-465. [CrossRef]

20. Ribeiro, D.V.; Paula, G.R.; Morelli, M.R. Effect of boric acid content on the properties of magnesium phosphate cement. Constr. Build. Mater. 2019, 214, 557-564. [CrossRef]

21. Formosa, J.; Chimenos, J.M.; Lacasta, A.M.; Niubo, M. Interaction between low-grade magnesium oxide and boric acid in chemically bonded phosphate ceramics formulation. Ceram. Int. 2012, 38, 2483-2493. [CrossRef]

22. Jeon, I.K.; Qudoos, A.; Kim, H.G. Influence of carbonation curing on hydration and microstructure of magnesium potassium phosphate cement concrete. J. Build. Eng. 2021, 38, 102203. [CrossRef]

23. Tan, Y.; Yu, H.; Li, Y.; Wu, C.; Dong, J.; Wen, J. Magnesium potassium phosphate cement prepared by the byproduct of magnesium oxide after producing $\mathrm{Li}_{2} \mathrm{CO}_{3}$ from salt lakes. Ceram. Int. 2014, 40, 13543-13551. [CrossRef]

24. Chen, W.; Wu, C.; Yu, H.; Chen, Y.; Zheng, S. Effect of Calcined MgO-rich Byproduct from the Extraction of $\mathrm{Li}_{2} \mathrm{CO}_{3}$ on the Performance of Magnesium Phosphate Cement. J. Adv. Concr. Technol. 2017, 15, 749-759. [CrossRef]

25. Dong, J.; Xiao, X.; Li, Y.; Wen, J.; Zheng, W.; Cheng, C.; Yu, H. The influences of raw materials mass ratio on properties and microstructure of salt lake magnesium potassium phosphate cement. Mater. Rep. B 2020, 34, 10041-10045.

26. Lahalle, H.; Coumes, C.C.D.; Mercier, C.; Lambertin, D.; Cannes, C.; Delpech, S.; Gauffinet, S. Influence of the w/c ratio on the hydration process of a magnesium phosphate cement and on its retardation by boric acid. Cem. Concr. Res. 2018, 109, 159-174. [CrossRef] 
27. Hou, D.; Yan, H.; Zhang, J.; Wang, P.; Li, Z. Experimental and computational investigation of magnesium phosphate cement mortar. Constr. Build. Mater. 2016, 112, 331-342. [CrossRef]

28. Xu, B.; Winnefeld, F.; Kaufmann, J.; Lothenbach, B. Influence of magnesium-to-phosphate ratio and water-to-cement ratio on hydration and properties of magnesium potassium phosphate cements. Cem. Concr. Res. 2019, 123, 105781. [CrossRef]

29. Li, Y.; Sun, J.; Chen, B. Experimental study of magnesia and M/P ratio influencing properties of magnesium phosphate cement. Constr. Build. Mater. 2014, 65, 177-183. [CrossRef]

30. Graeser, S.; Postl, W.; Bojar, H.P.; Berlepsch, P.; Armbruster, T.; Raber, T.; Ettinger, K.; Walter, F. Struvite-(K), $\mathrm{KMgPO}_{4} \cdot 6 \mathrm{H}_{2} \mathrm{O}$, the potassium equivalent of struvite-A new mineral. Eur. J. Miner. 2008, 20, 629-663. [CrossRef]

31. Sugama, T.; Kukacka, L.E. Characteristics of magnesium polyphosphate cements derived from ammonium polyphosphate solutions. Cem. Concr. Res. 1983, 13, 499-506. [CrossRef]

32. Zhang, J.; Li, S.; Li, Z.; Liu, C.; Gao, Y.; Qi, Y. Properties of red mud blended with magnesium phosphate cement paste: Feasibility of grouting material preparation. Constr. Build. Mater. 2020, 260, 119704. [CrossRef]

33. Xu, B.; Lothenbach, B.; Winnefeld, F. Influence of wollastonite on hydration and properties of magnesium potassium phosphate cements. Cem. Concr. Res. 2020, 131, 106012. [CrossRef]

34. Gardner, L.J.; Walling, S.A.; Corkhill, C.L.; Bernal, S.A.; Lejeune, V.; Stennett, M.C.; Provis, J.L.; Hyatt, N.C. Temperature transformation of blended magnesium potassium phosphate cement binders. Cem. Concr. Res. 2021, 141, 106332. [CrossRef]

35. Kulikova, S.A.; Danilov, S.S.; Belova, K.Y.; Rodionova, A.A.; Vinokurov, S.E. Optimization of the Solidification Method of High-Level Waste for Increasing the Thermal Stability of the Magnesium Potassium Phosphate Compound. Energies 2020, 13, 3789. [CrossRef]

36. Walling, S.A.; Provis, J.L. Magnesia-based cements: A journey of 150years, and cements for the future. Chem. Rev. 2016, 116, 4170-4204. [CrossRef]

37. Zheng, D.; Ji, T.; Wang, C.; Sun, C.; Lin, X.; Hossain, K.M.A. Effect of the combination of fly ash and silica fume on water resistance of Magnesium-Potassium Phosphate Cement. Constr. Build. Mater. 2016, 106, 415-421. [CrossRef]

38. Qian, Z.; Yu, B.; Zhou, S.; Qiao, Y.; Liu, X.; Wang, S.; Qin, Q.; Ma, J.; Wu, X. Influence of silica fume on radioactive fluoride concentrate liquid waste solidified by magnesium potassium phosphate cement. J. Radioanal. Nucl. Chem. 2020, 324, 1013-1019. [CrossRef]

39. Shi, C.; Yang, J.; Yang, N.; Chang, Y. Effect of waterglass on water stability of potassium magnesium phosphate cement paste. Cem. Concr. Compos. 2014, 53, 83-87. [CrossRef]

40. Bouaoun, I.; Hammi, H.; Aït-Mokhtar, A.; Hamami, A.E.; M'Nif, A. Effect of calcination temperature of magnesium silicate on the properties of magnesium phosphate cement. J. Aust. Ceram. Soc. 2017, 53, 351-359. [CrossRef]

41. Zheng, W.; Xiao, X.; Chang, C.; Dong, J.; Wen, J.; Huang, Q.; Zhou, Y.; Li, Y. Characterizing properties of magnesium oxychloride cement concrete pavement. J. Cent. South Univ. 2019, 26, 3410-3419. [CrossRef]

42. Zheng, W.; Xiao, X.; Wen, J.; Chang, C.; An, S.; Dong, J. Water-to-Cement Ratio of Magnesium Oxychloride Cement Foam Concrete with Caustic Dolomite Powder. Sustainability 2021, 13, 2429. [CrossRef]

43. Ma, H.; Xu, B.; Li, Z. Magnesium potassium phosphate cement paste: Degree of reaction, porosity and pore structure. Cem. Concr. Res. 2014, 65, 96-104. [CrossRef]

44. Liu, R.; Yang, Y.; Sun, S. Effect of M/P and Borax on the Hydration Properties of Magnesium Potassium Phosphate Cement Blended with Large Volume of Fly Ash. J. Wuhan Univ. Technol. Mater. Sci. Ed. 2017, 33, 1159-1167. [CrossRef]

45. Lahalle, H.; Céline, C.D.C.; Mesbah, A.; Lambertin, D.; Cannes, C.; Delpech, S.; Gauffinet, S. Investigation of magnesium phosphate cement hydration in dilutedsuspension and its retardation by boric acid. Cem. Concr. Res. 2016, 87, 77-86. [CrossRef]

46. Gardner, L.J.; Bernal, S.A.; Walling, S.A.; Corkhill, C.L.; Provis, J.L.; Hyatt, N.C. Characterization of magnesium potassium phosphate cements blended with fly ash and ground granulated blastfurnace slag. Cem. Concr. Res. 2015, 74, 78-87. [CrossRef]

47. Zhang, Y.; Wang, S.; Li, L.; Han, J.; Zhang, B.; Hou, D.; Wang, J.; Lin, C. A preliminary study of the properties of potassium phosphate magnesium cement-based grouts admixed with metakaolin, sodium silicate and bentonite. Constr. Build. Mater. 2020, 262, 119893. [CrossRef] 